Article

\title{
Rare Earth Elements (REE) in Al- and Fe-(Oxy)-Hydroxides in Bauxites of Provence and Languedoc (Southern France): Implications for the Potential Recovery of REEs as By-Products of Bauxite Mining
}

\author{
Nicola Mondillo ${ }^{1,2, *}$, Giuseppina Balassone ${ }^{1}$, Maria Boni ${ }^{1,2}$, Cyril Chelle-Michou ${ }^{3}{ }^{(1)}$, \\ Salvatore Cretella ${ }^{1} \mathbb{D}$, Angela Mormone ${ }^{4}$, Francesco Putzolu ${ }^{1}{ }^{1}$, Licia Santoro ${ }^{2}$, \\ Gennaro Scognamiglio ${ }^{1}$ and Marcella Tarallo ${ }^{1}$ \\ 1 Dipartimento di Scienze della Terra, dell'Ambiente e delle Risorse, Università degli Studi di Napoli \\ Federico II, 80126 Napoli, Italy \\ 2 Department of Earth Sciences, Natural History Museum, London SW7 5BD, UK \\ 3 Institute of Geochemistry and Petrology, Department of Earth Sciences, 8092 ETH Zurich, Switzerland \\ 4 INGV Osservatorio Vesuviano, 80125 Napoli, Italy \\ * Correspondence: nicola.mondillo@unina.it; Tel.: +39-081-253-5067
}

Received: 23 July 2019; Accepted: 20 August 2019; Published: 22 August 2019

check for

\begin{abstract}
Bauxites in southern France (Provence and Languedoc) have been exploited since the beginning of the last century. Though most of the deposits are now subeconomic or mined-out, these bauxites represent model analogs for other economic bauxites of the world. These Cretaceous karst-type deposits lie directly on Jurassic carbonates, and have been formed through a combination of different processes: in-situ alteration of siliciclastic sediments deposited on carbonate platforms, and reworking of early bauxites in the karst network. In this study, we present preliminary bulk rock geochemical and in-situ laser ablation (LA) -ICP-MS analyses on Al- and Fe-oxy-hydroxides of Provence (Les Baux-de-Provence) and Languedoc (Villeveyrac, Loupian) bauxites, with the aim of evaluating the concentrations of rare earth elements (REEs) and their deportment in these minerals. REEs have total average concentrations of $700 \mathrm{mg} / \mathrm{kg}$ in the analyzed samples, which are mostly composed of boehmite, $\gamma$ - $\mathrm{AlO}(\mathrm{OH})$, and Fe-oxy-hydroxides (hematite and goethite). Maximum REEs concentrations are commonly associated with positive Ce anomalies in chondrite-normalized patterns. In contrast with other examples from the literature, it has been observed that high REE concentrations also occur in samples apparently devoid or poor of REE-minerals. In these samples, the total amount of REEs is positively correlated with that of $\mathrm{Ga}$ (commonly contained in boehmite). LA-ICP-MS trace element analyses on boehmite and Fe-oxy-hydroxides have shown that while the Al-hydroxide contains the suite of REEs, goethite and hematite are preferentially enriched only in Ce. Considering that Al-hydroxides are digested during the Bayer process, an interesting issue to develop in the future is whether (and how) REEs released during Al-hydroxide digestion could be recovered together with $\mathrm{Al}$ from the pregnant leach liquor, as routinely done for $\mathrm{Ga}$.
\end{abstract}

Keywords: bauxite; Provence; Languedoc; rare earth elements; laser ablation (LA)-ICP-MS; boehmite; hematite; goethite; Bayer process

\section{Introduction}

Bauxite deposits are economic concentrations of aluminum, representing residual products of weathering and leaching of aluminosilicate parent rocks. These deposits typically form in humid, 
tropical to subtropical climates, with annual rainfalls in excess of $1.2 \mathrm{~m}$ and annual mean temperatures higher than $22^{\circ} \mathrm{C}$ [1]. Bauxites can be subdivided in lateritic bauxites formed in lateritic soil profiles, and karst bauxites that instead occurs on carbonate rocks [2]. Aluminum in bauxites occurs primarily in the form of gibbsite $\left[\mathrm{Al}(\mathrm{OH})_{3}\right]$ or amorphous $\mathrm{Al}$ hydroxides. Boehmite $[\gamma-\mathrm{AlO}(\mathrm{OH})]$, and diaspore $[\alpha-\mathrm{AlO}(\mathrm{OH})]$ (both less hydrated than gibbsite), typically occur in bauxites subjected to several diagenetic stages and/or metamorphism, or in metabauxites [3]. Iron is separated from aluminum and is generally concentrated as hematite and subordinately as goethite. Anatase $\left(\mathrm{TiO}_{2}\right)$, kaolinite $\left[\mathrm{Al}_{2} \mathrm{Si}_{2} \mathrm{O}_{5}(\mathrm{OH})_{4}\right]$ and other clays can also be present in bauxites in various proportions [3].

The bauxite resources of the world are estimated to be 55-75 billion tonnes, occurring in Africa (32\%), Oceania (23\%), South America and the Caribbean (21\%), Asia (18\%), and elsewhere (6\%) [4]. Approximately $70-80 \%$ of the world's bauxite production is processed first into alumina (Bayer process [5]), and then into aluminum by smelting and electrolysis (Hall-Hérault process). The modern version of the Bayer process still maintains the key steps of dissolution of alumina-rich minerals in a hot caustic solution and separation of the insoluble phases, followed by Al hydroxide precipitation and calcination to alumina $\left(\mathrm{Al}_{2} \mathrm{O}_{3}\right)$ [5]. The main advantage of the Bayer process is that the soda dissolution treatment specifically affects aluminum-containing minerals, and thus minimizes the dissolution of other mineral phases [5]. This digestion is achieved in a strongly alkaline solution at temperatures above $100{ }^{\circ} \mathrm{C}$ (the reaction for boehmite-rich bauxite is carried out at more than $240{ }^{\circ} \mathrm{C}$ ), so that minerals such as gibbsite and boehmite are dissolved to produce $\left(\mathrm{Al}(\mathrm{OH})_{4}\right)^{-}$(aluminate) ions in solution [5]. The insoluble phases of bauxite (i.e., the residue, called red mud or sludge) are separated from the main liquor and washed to recover soda and aluminum. Aluminum in solution in the liquor is precipitated to $\mathrm{Al}(\mathrm{OH})_{3}$ and/or $\mathrm{AlOOH}$, which are finally calcined to alumina $\left(\mathrm{Al}_{2} \mathrm{O}_{3}\right)$ [5].

Recently, significant attention has been paid to the processes that control the distribution and possible extraction techniques of several minor elements in bauxite deposits, specifically to those (for example, rare earth elements-REEs, Ga, Sc) considered critical for western countries and the European Union, because of their high economic importance and high supply risk on the international markets [6-19]. Currently, only gallium is commonly recovered as a by-product of processing bauxite, where it occurs with average concentrations of $50 \mathrm{mg} / \mathrm{kg}$ [20], as it is released from gibbsite, boehmite, and diaspore during the digestion stage of the Bayer process [21]. There is an ongoing debate on considering bauxite deposits as potential resources of REEs [4,22-28]. Several studies were mainly focused on the occurrence of REE-bearing minerals in red muds and on the REE mobility during the Bayer process. In particular, Vind et al. [27] have shown that during the Bayer process, while Ga, V, As, and $\mathrm{Cr}$ are principally accumulated in process liquors, most of the other trace elements (REE and Sc) have the tendency to remain unaffected in solid phases, fully ending up in the bauxite residue. Vind et al. [27] have also shown that the most abundant phase containing REEs in the residue of Greek bauxites is a LREE ferrotitanate $\left[(\mathrm{REE}, \mathrm{Ca}, \mathrm{Na})(\mathrm{Ti}, \mathrm{Fe}) \mathrm{O}_{3}\right]$ compound, considered to have formed during the digestion of precursor LREE-minerals during the Bayer process. Minor amounts of LREEs occurred as carbonates and phosphates, while heavy REEs were found associated with a Y-phosphate phase [27].

In this study, we present bulk rock geochemical and in-situ laser ablation-inductively coupled plasma mass spectrometric (LA-ICP-MS) analyses on Al- and Fe-oxy-hydroxides hosted in bauxite deposits in southern France with the aim of evaluating REE concentrations and deportment of in these minerals. We collected samples from old bauxite mines in Provence (Les Baux-de-Provence) and Languedoc (Villeveyrac, Loupian) (Figure 1). Today, France has a small bauxite market, but this country had a historic total bauxite production of around $101 \mathrm{Mt}$, from 1885 to 1991. In 1972, France, together with Hungary and Greece, supplied more than $11 \%$ of the world's bauxite production (http://sigminesfrance.brgm.fr/). The bauxite deposits of southern France are karst-type bauxites, associated with stratigraphic breaks in the Jurassic-Cretaceous carbonate successions [29-32]. They have been formed between the Albian and early Cenomanian, through a combination of different processes: in-situ alteration of siliciclastic sediments deposited on emerged carbonate platforms, and reworking of early bauxites in the karst network [30-32]. Siliciclastic sediments originated from the 
erosion of the exposed Hercynian basement (e.g., Massif Central, Maures Massif), nearby the carbonate platforms [30-32]. These deposits mainly contain a boehmite-gibbsite mineralization [30-32], and can be considered as model analogs of economic karst bauxites located in other regions of the world.

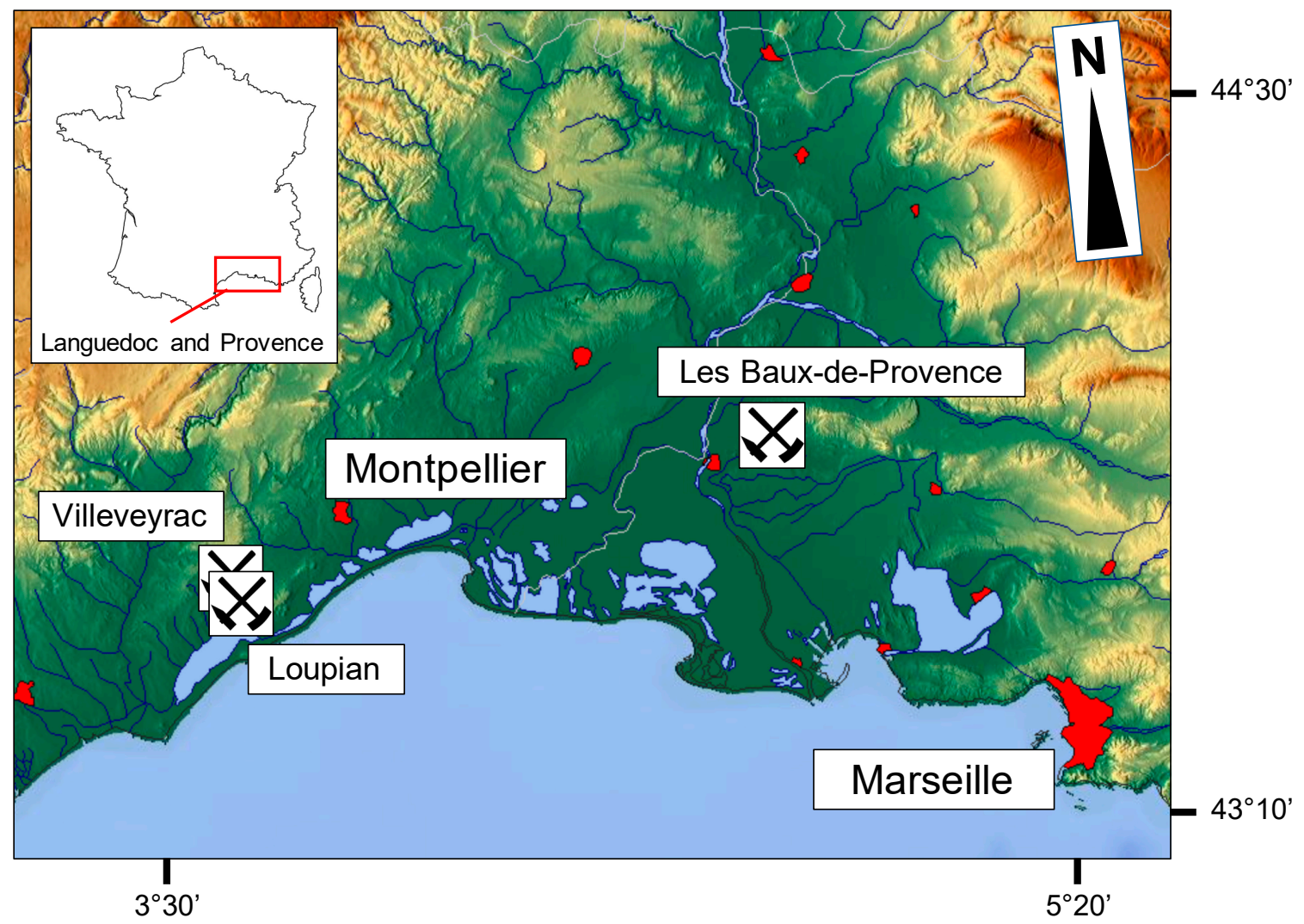

Figure 1. Relief map of Provence and Languedoc (southern France), with the approximate positions of the old bauxite mines object of sampling (https://maps-for-free.com).

\section{Materials and Methods}

Studies were performed on one sample from Provence (Les Baux-de-Provence) and three from Languedoc (Villeveyrac, Loupian) bauxite deposits (Figure 2, Table 1). Two samples from Loupian were collected at the top and the bottom of the bauxite profile. The samples were subdivided into two halves: the first one was used to prepare polished blocks for optical and scanning electron microscopy equipped with energy-dispersive X-ray spectroscopy (SEM-EDS), whereas the second was milled to produce powder for whole-rock X-ray powder diffraction (XRPD) and chemical analyses. Blocks were mounted in bi-component epoxy resin (SpeciFix20), polished with diamond suspension $(1 \mu \mathrm{m})$ and alumina $\mathrm{Al}_{2} \mathrm{O}_{3}(0.3 \mu \mathrm{m})$, and carbon-coated prior to SEM analysis.

Qualitative XRPD analyses were performed with a Seifert-GE ID3003 diffractometer, with CuK $\alpha$ radiation, $\mathrm{Ni}$-filtered at $40 \mathrm{kV}$ and $30 \mathrm{~mA}, 3-80^{\circ} 2 \theta$ range, step scan $0.02^{\circ}$, time $10 \mathrm{~s} / \mathrm{step}$ at the Dipartimento di Scienze della Terra, dell'Ambiente e delle Risorse (DiSTAR) University of Naples Federico II (Italy). Raw data were treated by the RayfleX (GE) software package. Semi-quantitative XRPD analyses were carried out by using X'Pert PRO diffractometer by PANalytical, at the Istituto Nazionale di Geofisica e Vulcanologia-Osservatorio Vesuviano (Napoli), with a high speed PIXcel detector, Ni-filtered, $\mathrm{CuK} \alpha$ radiation, pyrolytic graphite crystal monochromator, at $40 \mathrm{kV}$ and $40 \mathrm{~mA}$ in a $3-70^{\circ} 2 \theta$ range with $0.02^{\circ}$ steps at $8 \mathrm{~s} /$ step. Diffraction patterns were interpreted using the HighScore Plus software and JCPDS PDF-2 database. Mineral abundances were determined on the basis of the peak intensity ratio between mineral phases, and of the whole rock chemical analyses. 

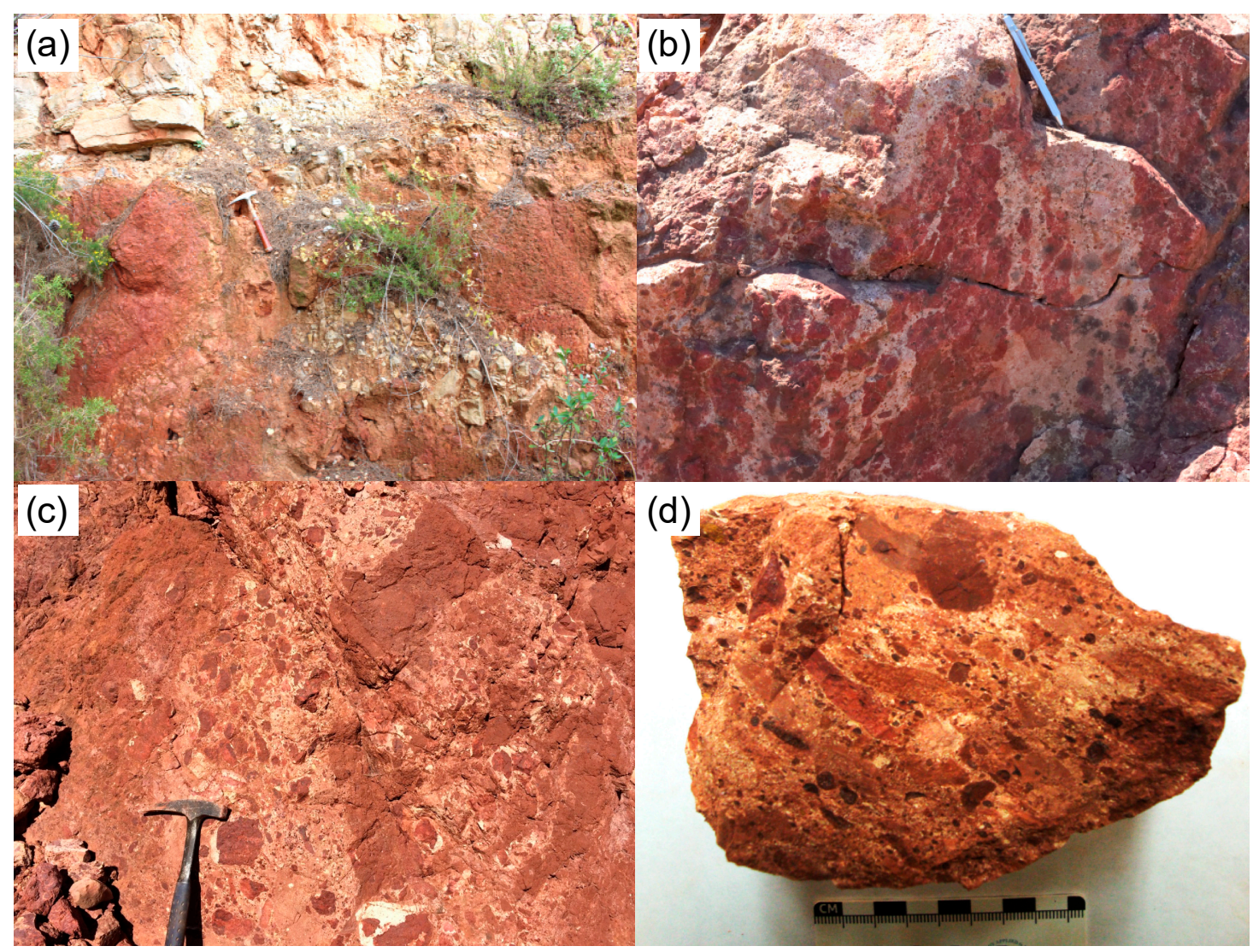

Figure 2. Outcrops and samples from localities included in this study: (a) Les Baux-de-Provence: top part of the bauxite profile, (b) Villeveyrac: bleached structure in the bauxite horizon, (c) Loupian: detrital features at the outcrop scale, (d) Loupian: sample LUP_A15.

Table 1. (a) Locations, (b) mineralogy and (c) major, minor and trace element compositions of the studied bauxite samples.

\begin{tabular}{|c|c|c|c|c|}
\hline \multicolumn{3}{|c|}{ (a) } & \multirow[b]{2}{*}{ LUP_A4 } & \multirow[b]{2}{*}{ LUP_A15 } \\
\hline Locations & LBP 7 & Vil IV-5 & & \\
\hline Latitude & $43^{\circ} 44^{\prime} 13^{\prime \prime} \mathrm{N}$ & $43^{\circ} 30^{\prime} 16^{\prime \prime} \mathrm{N}$ & $43^{\circ} 27^{\prime} 27^{\prime \prime} \mathrm{N}$ & $43^{\circ} 27^{\prime} 26^{\prime \prime} \mathrm{N}$ \\
\hline Longitude & $4^{\circ} 46^{\prime} 20^{\prime \prime} \mathrm{E}$ & $3^{\circ} 37^{\prime} 52^{\prime \prime} \mathrm{E}$ & $3^{\circ} 38^{\prime} 01^{\prime \prime} \mathrm{E}$ & $3^{\circ} 38^{\prime} 01^{\prime \prime} \mathrm{E}$ \\
\hline \multicolumn{3}{|c|}{ (b) } & & \\
\hline Mineral & LBP 7 & Vil IV-5 & LUP_A4 & LUP_A15 \\
\hline & \multicolumn{4}{|c|}{ Min-Max (wt.\%) } \\
\hline kaolinite & $16-17$ & $39-40$ & $4-5.5$ & $4-5$ \\
\hline boehmite & $53-58$ & $22-23$ & $63-68$ & $76-77$ \\
\hline goethite & $4-10$ & $10-11$ & $10-17$ & $0.5-1$ \\
\hline hematite & $15-22$ & $22-27$ & $10-20$ & $12-15$ \\
\hline anatase & $2-2.3$ & $1.7-1.9$ & $3.1-3.7$ & $2.5-3.4$ \\
\hline calcite & - & 3 & - & - \\
\hline
\end{tabular}


Table 1. Cont.

\begin{tabular}{|c|c|c|c|c|c|c|}
\hline Method & Analyte & Det. Lim. & LBP 7 & Vil IV-5 & LUP_A4 & LUP_A15 \\
\hline \multicolumn{7}{|l|}{ wt. $\%$} \\
\hline XF701 & $\mathrm{SiO}_{2}$ & 0.01 & 8.14 & 18.30 & 2.53 & 2.28 \\
\hline XF701 & $\mathrm{Al}_{2} \mathrm{O}_{3}$ & 0.01 & 51.90 & 34.30 & 55.00 & 66.40 \\
\hline XF701 & $\mathrm{TiO}_{2}$ & 0.01 & 2.32 & 1.85 & 3.74 & 3.39 \\
\hline XF701 & $\mathrm{Fe}_{2} \mathrm{O}_{3}$ & 0.01 & 24.10 & 32.50 & 24.90 & 13.30 \\
\hline XF701 & $\mathrm{Cr}_{2} \mathrm{O}_{3}$ & 0.001 & 0.07 & 0.04 & 0.05 & 0.04 \\
\hline XF701 & $\mathrm{CaO}$ & 0.01 & 0.10 & 1.67 & 0.08 & 0.26 \\
\hline XF701 & $\mathrm{MgO}$ & 0.01 & 0.07 & 0.12 & 0.14 & 0.08 \\
\hline XF701 & $\mathrm{MnO}$ & 0.01 & 0.03 & 0.02 & 0.05 & 0.05 \\
\hline XF701 & $\mathrm{Na}_{2} \mathrm{O}$ & 0.01 & 0.04 & 0.06 & 0.04 & 0.04 \\
\hline XF701 & $\mathrm{K}_{2} \mathrm{O}$ & 0.01 & $<0.01$ & 0.06 & $<0.01$ & $<0.01$ \\
\hline XF701 & $\mathrm{P}_{2} \mathrm{O}_{5}$ & 0.001 & 0.14 & 0.24 & 0.16 & 0.10 \\
\hline XF701 & $\mathrm{V}_{2} \mathrm{O}_{5}$ & 0.001 & 0.10 & 0.09 & 0.09 & 0.07 \\
\hline XF701 & $\mathrm{ZrO}_{2}$ & 0.01 & 0.08 & 0.08 & 0.09 & 0.09 \\
\hline XF701 & $\mathrm{SO}_{3}$ & 0.01 & 0.03 & 0.01 & 0.02 & 0.03 \\
\hline XF701 & LOI & & 12.40 & 10.60 & 12.80 & 13.30 \\
\hline \multicolumn{7}{|l|}{$\mathrm{mg} / \mathrm{kg}$} \\
\hline LF100 & $\mathrm{Ba}$ & 1 & 14 & 26 & 11 & 11 \\
\hline LF100 & $\mathrm{Be}$ & 1 & 2 & 5 & 9 & 5 \\
\hline LF100 & $\mathrm{Co}$ & 0.2 & 14.8 & 18.8 & 37.1 & 18.1 \\
\hline LF100 & Cs & 0.1 & $<0.1$ & 0.5 & $<0.1$ & $<0.1$ \\
\hline LF100 & $\mathrm{Ga}$ & 0.5 & 66.4 & 38.3 & 66.9 & 70.5 \\
\hline LF100 & Hf & 0.1 & 21.2 & 19.8 & 25.8 & 28.3 \\
\hline LF100 & $\mathrm{Nb}$ & 0.1 & 51.9 & 40.3 & 78.4 & 74.2 \\
\hline LF100 & $\mathrm{Rb}$ & 0.1 & 0.4 & 2.3 & $<0.1$ & $<0.1$ \\
\hline LF100 & Sn & 1 & 12 & 9 & 15 & 15 \\
\hline LF100 & $\mathrm{Sr}$ & 0.5 & 122.4 & 379.8 & 196 & 72.8 \\
\hline LF100 & $\mathrm{Ta}$ & 0.1 & 3.7 & 2.9 & 5.4 & 4.9 \\
\hline LF100 & Th & 0.2 & 51 & 35.3 & 45.6 & 49.4 \\
\hline LF100 & $\mathrm{U}$ & 0.1 & 13.3 & 7.6 & 17.4 & 16 \\
\hline LF100 & $\mathrm{V}$ & 8 & 538 & 484 & 469 & 377 \\
\hline LF100 & W & 0.5 & 6.9 & 5.6 & 8.6 & 9.7 \\
\hline LF100 & $\mathrm{Zr}$ & 0.1 & 773.0 & 733.1 & 991.3 & 1117.4 \\
\hline LF100 & $\mathrm{Y}$ & 0.1 & 52.0 & 84.6 & 85.4 & 62.8 \\
\hline LF100 & $\mathrm{La}$ & 0.1 & 230.3 & 147.5 & 117.5 & 81.1 \\
\hline LF100 & $\mathrm{Ce}$ & 0.1 & 401.1 & 326.2 & 383.8 & 116 \\
\hline LF100 & $\operatorname{Pr}$ & 0.02 & 49.69 & 29.66 & 19.95 & 10.80 \\
\hline LF100 & $\mathrm{Nd}$ & 0.3 & 178.2 & 105.1 & 64.7 & 28.7 \\
\hline LF100 & $\mathrm{Sm}$ & 0.05 & 30.63 & 20.04 & 11.64 & 5.10 \\
\hline LF100 & $\mathrm{Eu}$ & 0.02 & 4.96 & 4.08 & 2.48 & 1.18 \\
\hline LF100 & $\mathrm{Gd}$ & 0.05 & 16.06 & 18.49 & 12.18 & 5.98 \\
\hline LF100 & $\mathrm{Tb}$ & 0.01 & 1.88 & 2.79 & 2.17 & 1.33 \\
\hline LF100 & Dy & 0.05 & 10.21 & 15.79 & 14.19 & 9.54 \\
\hline LF100 & Ho & 0.02 & 1.88 & 3.08 & 3.03 & 2.22 \\
\hline LF100 & Er & 0.03 & 5.64 & 9.06 & 9.43 & 7.12 \\
\hline LF100 & $\mathrm{Tm}$ & 0.01 & 0.90 & 1.35 & 1.42 & 1.11 \\
\hline LF100 & $\mathrm{Yb}$ & 0.05 & 6.37 & 8.58 & 9.64 & 7.49 \\
\hline \multirow[t]{5}{*}{ LF100 } & $\mathrm{Lu}$ & 0.01 & 0.96 & 1.33 & 1.51 & 1.19 \\
\hline & $\sum \mathrm{REE}+\mathrm{Y}$ & & 990.78 & 777.65 & 739.04 & 341.66 \\
\hline & $\mathrm{Eu} / \mathrm{Eu}^{*}$ (cho) & & 0.68 & 0.65 & 0.64 & 0.65 \\
\hline & $(\mathrm{La} / \mathrm{Yb}) \mathrm{N}_{(\mathrm{cho})}$ & & 25.93 & 12.33 & 8.74 & 7.77 \\
\hline & $\mathrm{Ce} / \mathrm{Ce}^{*}(\mathrm{cho})$ & & 0.92 & 1.21 & 1.94 & 0.96 \\
\hline
\end{tabular}

Note: $\mathrm{Eu} / \mathrm{Eu}^{*}{ }_{(\mathrm{cho})},(\mathrm{La} / \mathrm{Yb}) \mathrm{N}_{(\mathrm{cho})}, \mathrm{Ce} / \mathrm{Ce}^{*}$ (cho) calculated as in [15]; chondrite (cho) values from [33]. 
Whole-rock chemical analyses of major and minor elements were carried out at Bureau Veritas Commodities Canada Ltd. (Vancouver, BC, Canada), on identical powder splits to those used for XRPD analyses. Moisture and loss on ignition (LOI) were determined separately at $105^{\circ} \mathrm{C}$ and $1000{ }^{\circ} \mathrm{C}$. For major elements analysis, dried samples were mixed with lithium tetraborate/metaborate flux followed by fusion and casting into glass discs, then analyzed by X-ray fluorescence (XRF, method XF701). Rare earth and refractory elements were determined by inductively coupled plasma-mass spectrometry (ICP-MS) following a $\mathrm{LiBO}_{2} / \mathrm{Li}_{2} \mathrm{~B}_{4} \mathrm{O}_{7}$ fusion (method LF100, Bureau Veritas Commodities Canada Ltd.).

Scanning electron microscopy (SEM)-EDS analyses were carried out by using a ZEISS EVO LS 15 scanning electron microscope (Natural History Museum, London, UK) at $20 \mathrm{kV}$, with $8.5 \mathrm{~mm}$ working distance and $3 \mathrm{nA}$ current mounting with X-Max detectors. A Co standard was used for the instrument calibration.

Laser ablation (LA)-ICP-MS analyses were carried out on an ASI NWR193 UV $193 \mathrm{~nm}$ short pulse width $(<4 \mathrm{~ns})$ laser fitted with a TwoVol2 ablation cell and coupled to an Agilent $7700 x$ quadrupole ICP-MS configured with dual external rotary pumps for enhanced sensitivity, located in the LODE Laboratory-Natural History Museum (London). Ablated spots were 35-50 $\mu \mathrm{m}$ in diameter, with a fluence of $3.5 \mathrm{~J} \cdot \mathrm{cm}^{-2}$, fired at a frequency of $10 \mathrm{~Hz}$. The transport gas used was $\mathrm{He}$ at a flow rate of $0.5 \mathrm{~L} \cdot \mathrm{min}^{-1}$ mixed with Ar at a flow rate of $1.1 \mathrm{~L} \cdot \mathrm{min}^{-1}$, in a signal-smoothing device. The element menus and ICP-MS dwell time settings that were employed to obtain the compositions of the various minerals are listed in the Supplementary material (Table S1). Element ratios to an internal standard element $\left({ }^{57} \mathrm{Fe}\right.$ for both Fe-oxy-hydroxides and Al-hydroxides) were determined by referencing background-corrected integrated intensities from mineral signals to the external calibration standard. This was GSD-1g glass (USGS). Absolute element concentrations were then calculated from internal standard element concentrations (predetermined by SEM-EDS) in the program ExLAM [34]. Limits of detection were set at the conventional $3 \sigma$ of the background signal variation [35]. NIST 2782, NIST 610, and BC_28 (the in-house magnetite standard of Dare et al. [36]) were also monitored during Al-hydroxide and Fe-oxy-hydroxide analysis. Contamination of the phase of interest by inclusions or the crossing of grain boundaries was avoided by monitoring a number of non-formula elements associated with these contaminant phases. Time-resolved raw cps signals were meticulously screened and the longest clean integration intervals possible (up to $60 \mathrm{~s}$ of signal) were retained. Analyses with significant contamination were discarded outright. Tuning was optimized for the whole mass range, and oxide formation (as represented by ${ }^{248} \mathrm{ThO} / 232 \mathrm{Th}$ ) and doubly-charged species formation (observed via ${ }^{22} \mathrm{Ca} /{ }^{44} \mathrm{Ca}$ ) were kept below $0.2 \%$.

\section{Results}

\subsection{Mineralogy and Geochemistry}

The analyzed samples are represented by oolitic bauxites, locally showing detrital features (Figure 2). The sample LBP 7, collected at the bottom of the Les Baux-de-Provence (hereafter Les Baux) bauxite horizon (Figure 2a), shows a matrix-supported texture characterized by centimetric to millimetric bauxite clasts in a boehmitic to Fe-boehmitic to boehmitic-kaolinitic matrix. The bauxite clasts are predominantly composed either of boehmite or hematite (Figure 3a). Boehmite-rich clasts commonly have a simple concretionary or complex oolitic structure (Figure 3b). Kaolinite and anatase were found as individual grains within the boehmitic matrix, which also contains detrital zircon, monazite, and xenotime. The LBP 7 sample has an $\mathrm{Al}_{2} \mathrm{O}_{3}$ concentration of $51.90 \mathrm{wt} . \%$, higher than $\mathrm{Fe}_{2} \mathrm{O}_{3}$ and $\mathrm{SiO}_{2}$ concentrations (24.10 wt. $\%$ and $8.14 \mathrm{wt} . \%$, respectively) (Table 1). $\mathrm{TiO}_{2}$ concentration is $2.32 \mathrm{wt} . \%$. Among the trace elements, there are significant concentrations of $\mathrm{Ga}(66 \mathrm{mg} / \mathrm{kg}), \mathrm{V}$ $(538 \mathrm{mg} / \mathrm{kg})$, and $\mathrm{Zr}(773 \mathrm{mg} / \mathrm{kg})$. The total amount of REE $+\mathrm{Y}$ is $990.78 \mathrm{mg} / \mathrm{kg}$. 

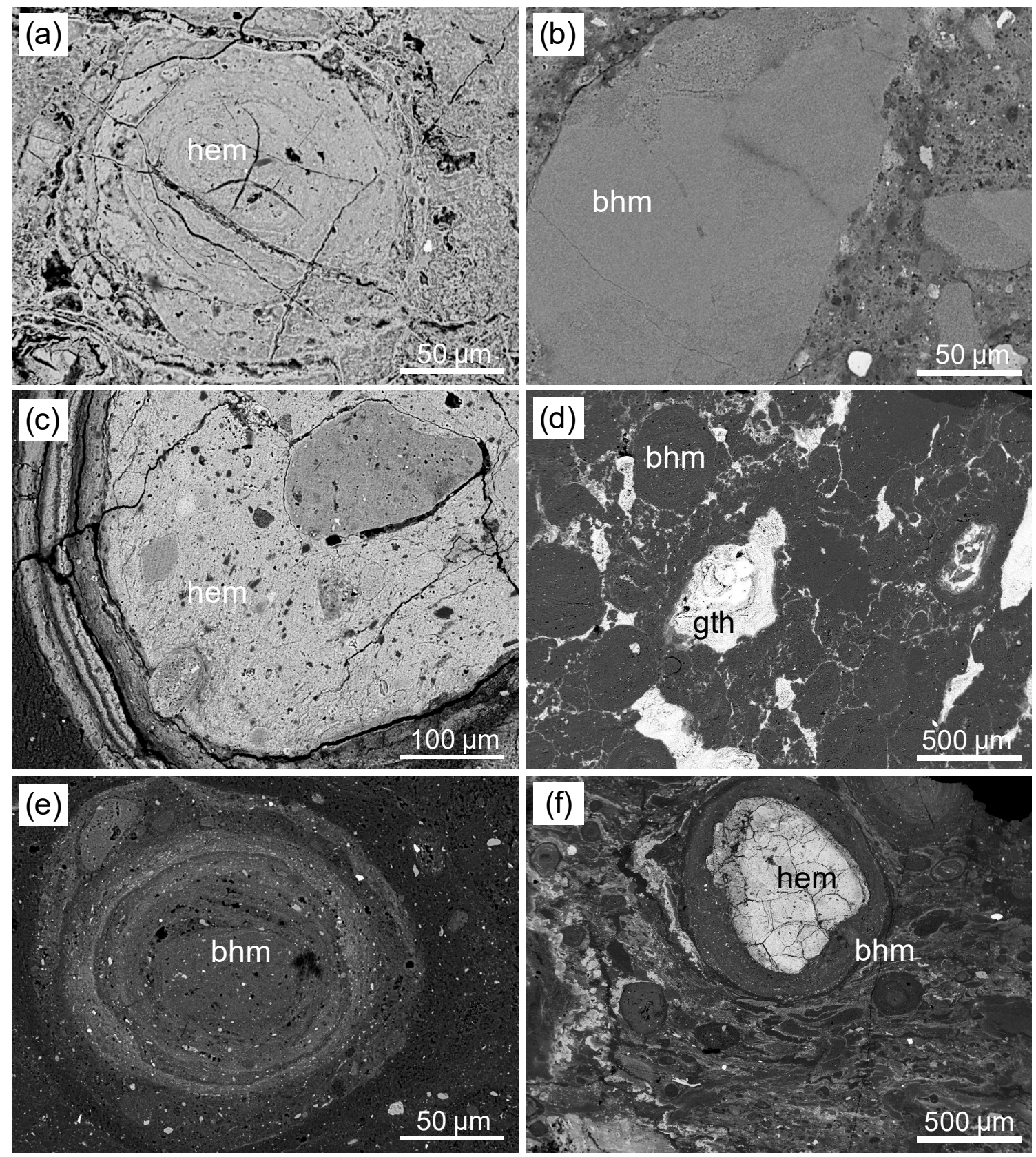

Figure 3. SEM (backscattered-electron) micrographs: (a) LBP 7: nucleus of a hematitic oolite, (b) LBP 7: boehmite-rich clasts, (c) Vil_IV5: complex hematitic oolite, (d) LUP_A4: goethite crusts and dendrites (bright) between the Al-hydroxides oolites (dark), (e) LUP_A15: boehmite oolite, (f) LUP_A15: oolite showing a hematite nucleus, and a boehmite rim, in a matrix of boehmitic micro-oolites showing compaction features. $\mathrm{bhm}=$ boehmite, hem $=$ hematite, $\mathrm{gth}=$ goethite

The Vil_IV5 (Villeveyrac) sample has a matrix-supported texture, characterized by less than $20 \%$ modal of clasts bigger than $2 \mathrm{~mm}$, and contains abundant kaolinite (Table 1). The sample shows typical bleaching streaks (Figure 2b), which confer to the sample a banded structure. The bands comprise alternating boehmite- to Fe-boehmite-rich zones, associated with kaolinite, and are locally cross-cut by veins of pure boehmite. Interestingly, most of the oolites occurring in this sample are composed of hematite (Figure 3c), whereas boehmite is concentrated in the sample matrix finely mixed with kaolinite. Detrital minerals are mostly represented by zircon, rutile, monazite, and xenotime. This sample shows approximately similar concentrations of $\mathrm{Al}_{2} \mathrm{O}_{3}$ and $\mathrm{Fe}_{2} \mathrm{O}_{3}(34.30 \mathrm{wt} . \%$ and $32.50 \mathrm{wt} . \%$, 
respectively), high $\mathrm{SiO}_{2}$ (18.30 wt.\%), and low $\mathrm{TiO}_{2}$ amounts (1.85 wt.\%) (Table 1). Gallium (38.3 mg/kg) and $\mathrm{V}(484 \mathrm{mg} / \mathrm{kg})$ are not as high as in the LBP 7 sample, whilst $\mathrm{Zr}$ shows a similar concentration $(733 \mathrm{mg} / \mathrm{kg})$. In this sample, the total amount of REE + Y is $777.65 \mathrm{mg} / \mathrm{kg}$.

The two samples from the Loupian deposit were collected at the top (LUP_A4, Figure 2c) and at the bottom (LUP_A15, Figure 2d) of the bauxite horizon. In the sample LUP_A15, the detrital features are more abundant than in sample LUP_A4. Specifically, in the matrix of the LUP_A15 (bottom) sample, it is possible to observe millimetric to sub-centimetric clasts of complex oolites or detrital bauxite, whereas in the LUP_A4 (top) the matrix contains very few detrital elements and bleaching structures prevail (Figure 2c,d). The matrix of both samples has a composition varying from boehmitic, to Fe-boehmitic, to kaolinitic. In the sample LUP_A4, as in the previous samples, oolites mostly comprise boehmite (Figure 3d). In the sample LUP_A15, boehmitic oolites and hematite fragments are common (Figure 3e). In addition, hematite and goethite commonly occur in crusts and dendriform concretions between the boehmitic oolites. In LUP_A4 goethite prevails over hematite (Table 1). Compaction structures can be observed in both samples (Figure 3f). Similarly to the Villeveyrac sample, the detrital minerals are mostly represented by zircon and rutile. Rare monazite and xenotime have also been detected.

The two samples from Loupian have contrasting chemical compositions (Table 1). Sample LUP_A15 has a higher concentration of $\mathrm{Al}_{2} \mathrm{O}_{3}\left(66.40\right.$ wt.\%) and a lower amount of $\mathrm{Fe}_{2} \mathrm{O}_{3}(13.30$ wt.\%) than sample LUP_A4 (55 wt.\% and $24.90 \mathrm{wt} . \%$, respectively). $\mathrm{SiO}_{2}$ and $\mathrm{TiO}_{2}$ amounts are quite similar in both samples (ca. $2.4 \mathrm{wt} . \%$ and ca. $3.5 \mathrm{wt} . \%$, respectively). Gallium is approximately $70 \mathrm{mg} / \mathrm{kg}$ in both samples, V is more abundant in LUP_A4 than in LUP_A15 (469 vs. $377 \mathrm{mg} / \mathrm{kg}$ ), whereas Zr has a higher concentration in LUP_A15 $(1117 \mathrm{mg} / \mathrm{kg})$. The total amount of REE + Y is higher in the sample LUP_A4 $(739 \mathrm{mg} / \mathrm{kg})$ than in sample LUP_A15 $(341.66 \mathrm{mg} / \mathrm{kg})$. On chondrite-normalized REE patterns, all the samples have approximately the same $\mathrm{Eu} / \mathrm{Eu}^{*}$ ratio (ca. 0.65), whereas the $\mathrm{Ce} / \mathrm{Ce}^{*}$ ratio yields contrasting values. In particular, LUP_A4 sample (top of the profile) shows a positive Ce anomaly $\left(\mathrm{Ce} / \mathrm{Ce}^{*}{ }_{(\text {cho })}=1.94\right)$, whilst LUP_A15 shows a slight negative $\mathrm{Ce}$ anomaly $\left(\mathrm{Ce} / \mathrm{Ce}^{*}{ }_{(\text {cho }}=0.96\right)$. Interestingly, no secondary authigenic REE-minerals (e.g., cerianite and REE-fluorocarbonates) have been detected in the analyzed samples.

\subsection{Mineral Composition and Laser Ablation (LA)-ICP-MS Analyses}

Mineral compositions have been evaluated through SEM-EDS and LA-ICP-MS analyses. The analyses have been carried out on Al-hydroxide (boehmite) and Fe-oxy-hydroxide (goethite and hematite) masses that were as homogeneous as possible (under backscattered electrons, BSE) and/or inclusions-free. However, due to the microgranular texture and porosity of the studied materials, in several cases the obtained compositions are quite far from the stoichiometric formulas of boehmite, hematite, and goethite, as accepted by the International Mineralogical Association (IMA). The concentrations resulting from the LA-ICP-MS analysis are represented with box-plots in Figures 4 and 5, and listed in detail in the Supplementary material (Tables S2 and S3).

\subsubsection{Al-Hydroxides}

In the Les Baux sample, boehmite is finely intergrown with Fe-oxy-hydroxides, resulting in very Fe-rich compositions $\left(\mathrm{Fe}_{2} \mathrm{O}_{3}>8-10 \mathrm{wt}\right.$.\%) under SEM-EDS. In the Villeveyrac sample, boehmite strictly coexists with kaolinite. This is reflected by high amounts of $\mathrm{SiO}_{2}(5-12 \mathrm{wt} . \%)$ in many SEM-EDS analyses. For this reason, in these samples, only the SEM-EDS spots containing less than $7 \mathrm{wt} \%$ $\mathrm{Fe}_{2} \mathrm{O}_{3}$ and $5 \mathrm{wt}$.\% $\mathrm{SiO}_{2}$, respectively, were analyzed by LA-ICP-MS. In the Loupian samples, the intergrowth between boehmite and other minerals is very limited. Inclusion-free (under the SEM) boehmite commonly shows $\mathrm{SiO}_{2}$ concentrations below 1 wt. $\%, \mathrm{Fe}_{2} \mathrm{O}_{3}$ below $5 \mathrm{wt}$ \% (on average around $2.5 \mathrm{wt.} \%)$, and $\mathrm{TiO}_{2}$ approximately $1 \mathrm{wt} . \%$. Alumina $\left(\mathrm{Al}_{2} \mathrm{O}_{3}\right)$ shows an average concentration of $78 \mathrm{wt} . \%$ (stoichiometric boehmite accepted by IMA has $\mathrm{Al}_{2} \mathrm{O}_{3}=83 \mathrm{wt} . \%$ ). 

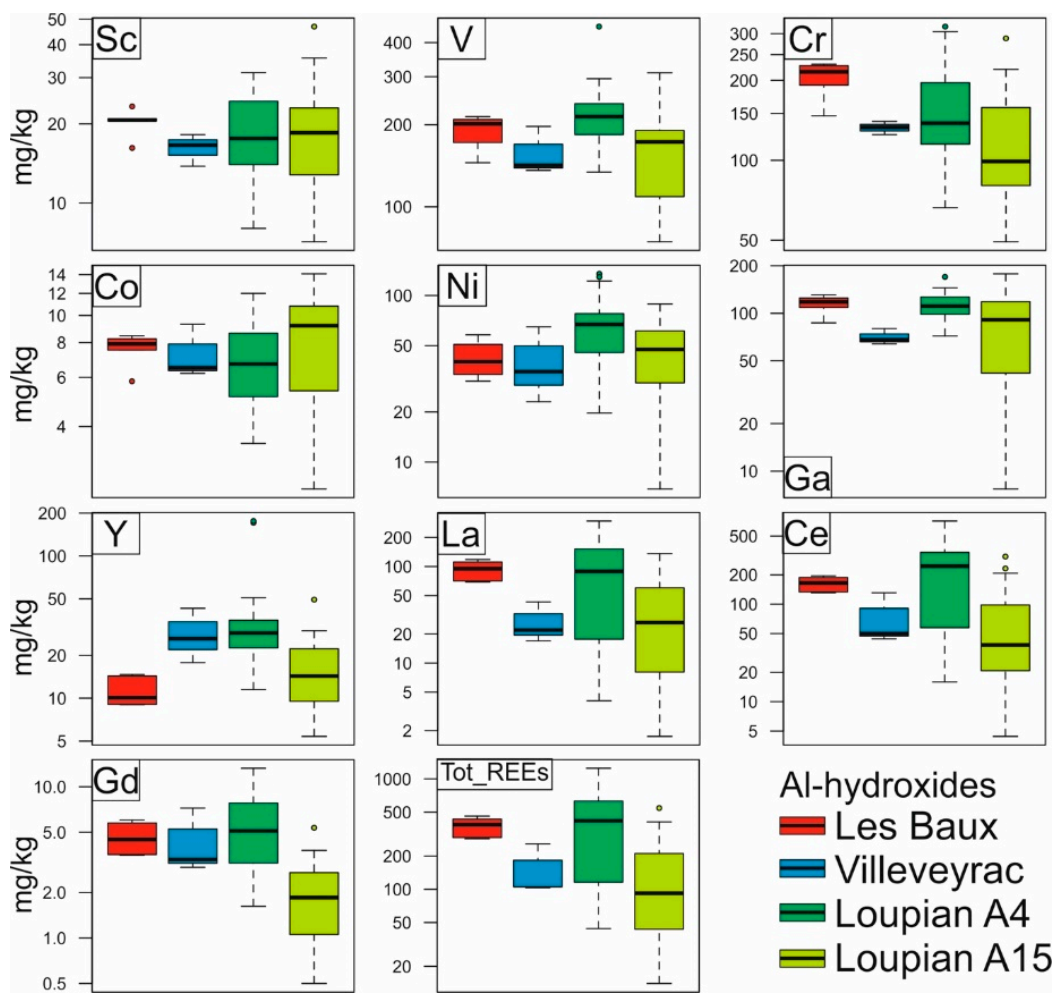

Figure 4. Boxplots reporting the compositions $(\mathrm{mg} / \mathrm{kg})$ of selected elements in the analyzed Al-hydroxides. Individual LA-ICP-MS analyses are given in Table S2.
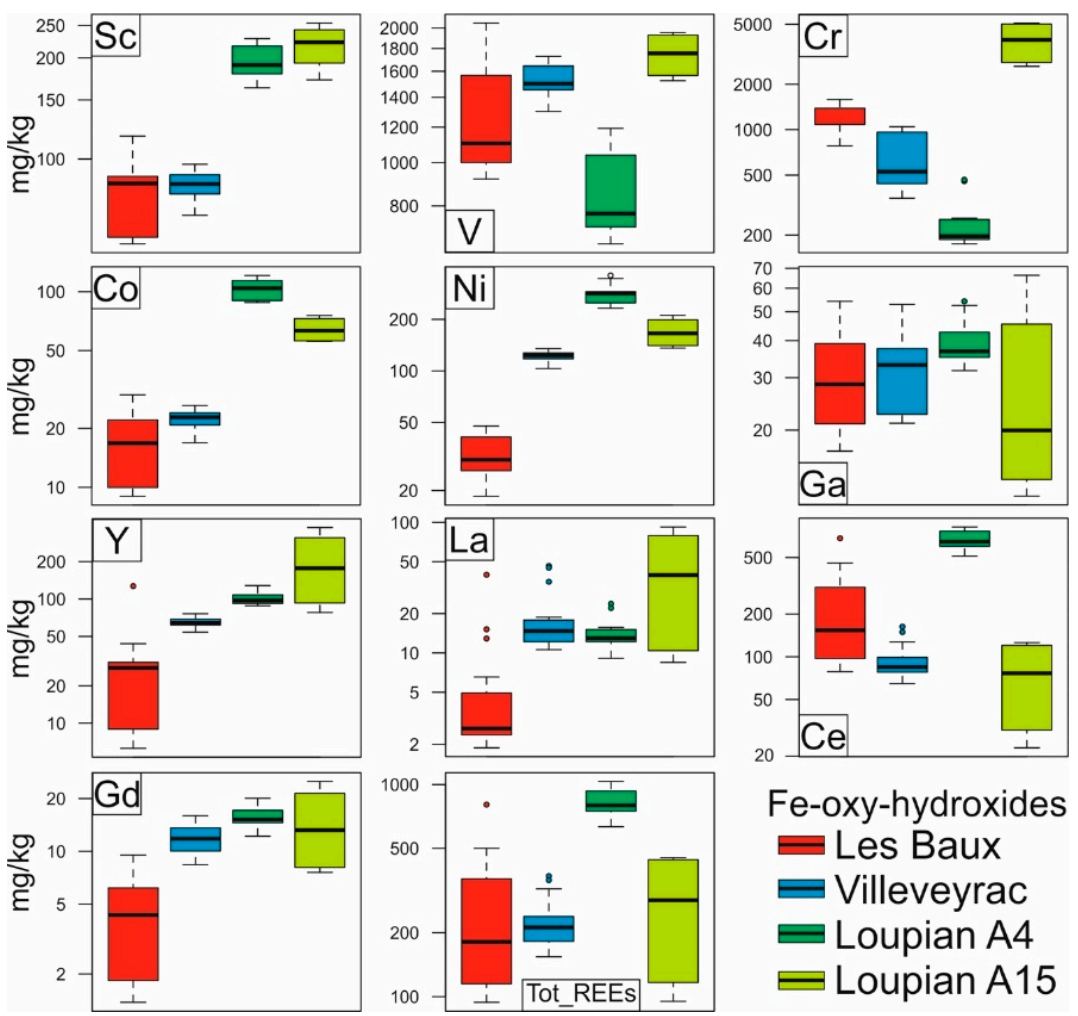

Fe-oxy-hydroxides

—Les Baux

EVilleveyrac

E Loupian A4

$\rightleftharpoons$ Loupian A15

Figure 5. Boxplots reporting the compositions $(\mathrm{mg} / \mathrm{kg})$ of selected elements in the analyzed Fe-oxy-hydroxides. Individual LA-ICP-MS analyses are given in Table S3. 
Even though the major element compositions of boehmite from the studied samples seem to be variously affected by the factors mentioned above, the minor and trace element concentrations measured by LA-ICP-MS are consistent through the studied samples. Among the measured bauxitophile elements, those showing the highest concentrations are $\mathrm{V}$ (average concentrations (avg.) in the analyzed samples from 180 to $200 \mathrm{mg} / \mathrm{kg}$ ), Cr (avg. in the analyzed samples from 100 to $220 \mathrm{mg} / \mathrm{kg}$ ), Ni (avg. in the analyzed samples from 45 to $60 \mathrm{mg} / \mathrm{kg}$ ), and Ga (avg. in the analyzed samples from 90 to $110 \mathrm{mg} / \mathrm{kg}$ ) (Figure 4). Given the high number of analyzed spots (more than 40), the Loupian samples show the widest standard deviation among the analyzed samples (Figure 4).

Interestingly, REE amounts were also detected in all the analyzed Al-hydroxides, with average total REE concentrations of: $374 \pm 74 \mathrm{mg} / \mathrm{kg}$ at Les Baux, $156 \pm 88 \mathrm{mg} / \mathrm{kg}$ at Villeveyrac, $395 \pm 296 \mathrm{mg} / \mathrm{kg}$ in Loupian A4, and $150 \pm 145 \mathrm{mg} / \mathrm{kg}$ in Loupian A15 (Figure 4). The chondrite-normalized diagrams (Figure 6a-d) showed REEs patterns characterized by enrichment of LREEs (La to Nd) over MREEs (Sm to $\mathrm{Tb}$ ) and HREEs (Dy to $\mathrm{Lu}$ ), and common slight positive Ce, accompanied by negative Eu anomalies. Moreover, as shown by the bauxite-normalized diagrams, the REE distribution in Al-hydroxides in the Les Baux and Villeveyrac samples resembles on average that of the respective bauxite samples (Figure 7a-d). HREEs are slightly depleted in respect to LREEs in the Les Baux sample, whereas they show a minor enrichment in the Villeveyrac sample. In the Loupian Al-hydroxides, the REEs/bauxite patterns are more complex, with relatively flat MREE and HREE patterns and variably enriched LREEs segments (Figure $7 \mathrm{e}-\mathrm{h}$ ). In particular, the $\mathrm{Al}$-hydroxides are characterized by negative $\mathrm{Ce}$ anomalies in the sample at the top of the profile, whilst the bottom profile sample shows positive Ce anomalies. $\mathrm{La}$ and $\mathrm{Ce}$ concentrations have a perfect positive correlation, as well as $\mathrm{Ce}$ and $\operatorname{Pr}$ (with the exception of the Fe-rich boehmite from Les Baux, Figure 8).
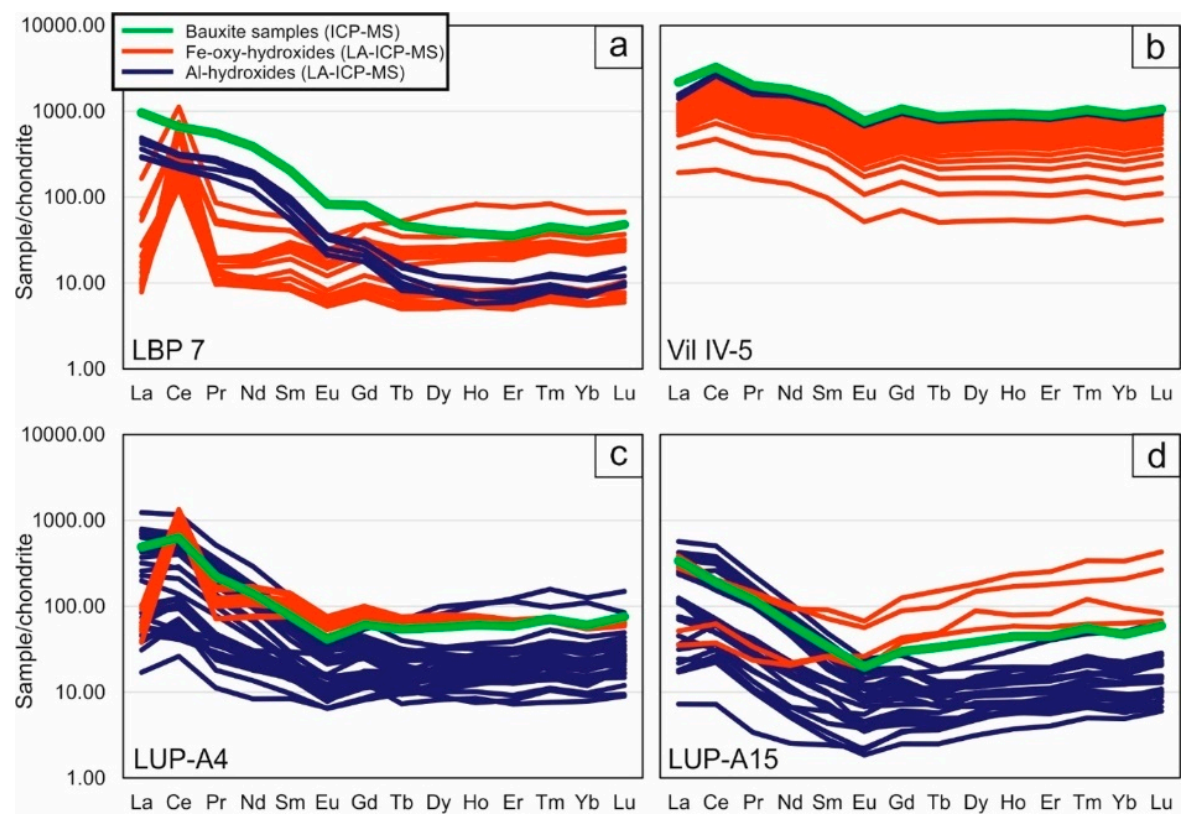

Figure 6. REE concentrations obtained on bulk bauxite samples and in-situ LA-ICP-MS analysis of Al- and Fe-(oxy)-hydroxides normalized to chondrite [33]: (a) Les Baux-de-Provence; (b) Villeveyrac; Loupian: samples at the (c) top and at the (d) bottom of the profile. 

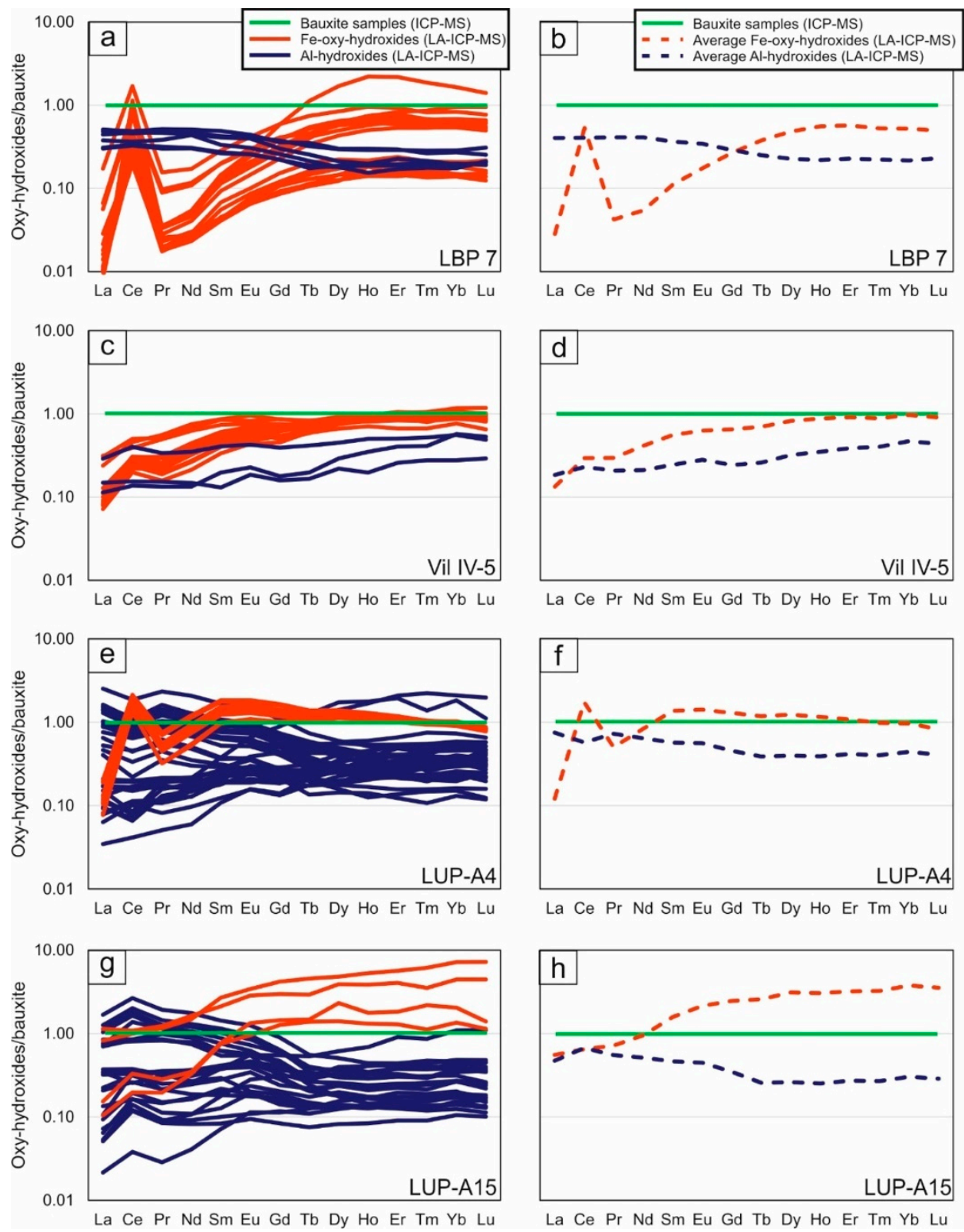

La Ce Pr Nd Sm Eu Gd Tb Dy Ho Er Tm Yb Lu

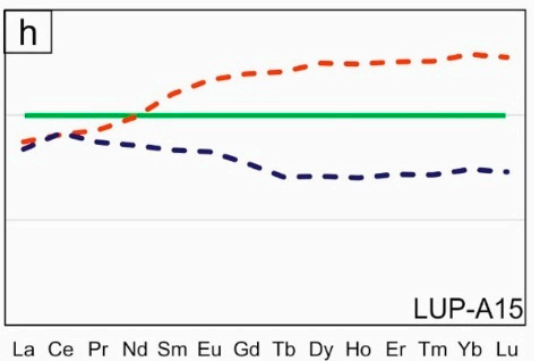

Figure 7. REE concentrations obtained with in-situ LA-ICP-MS analysis, normalized to the corresponding bulk bauxite samples. Les Baux-de-Provence Al- and Fe-(oxy)-hydroxide (a) individual data and (b) average compositions; Villeveyrac Al- and Fe-(oxy)-hydroxide (c) individual data and (d) average compositions; Loupian: top of the profile Al- and Fe-(oxy)-hydroxide (e) individual data and (f) average compositions; Loupian: bottom of the profile Al- and Fe-(oxy)-hydroxide (g) individual data and (h) average compositions.

\subsubsection{Fe-Oxy-Hydroxides}

The major and minor element compositions of Fe-oxy-hydroxides were analyzed in all the studied samples. In the Les Baux, Villeveyrac and Loupian A15 samples most of the analyses were carried out on hematite. However, in all the measured SEM-EDS spots in addition to Fe (avg. 90 wt. $\% \mathrm{Fe}_{2} \mathrm{O}_{3}$ ), $\mathrm{Al}_{2} \mathrm{O}_{3}$ (avg. $=3.4$ wt. \%), $\mathrm{SiO}_{2}$ (avg. $=0.9$ wt.\%), and $\mathrm{TiO}_{2}$ (avg. $=1.9 \mathrm{wt} . \%$ ) were also detected. In the Loupian A4 sample, goethite was the Fe-oxy-hydroxide analyzed: avg. $\mathrm{Fe}_{2} \mathrm{O}_{3}=80.8$ wt.\%, avg. $\mathrm{Al}_{2} \mathrm{O}_{3}$ $=2.2 \mathrm{wt} . \%$, avg. $\mathrm{SiO}_{2}=1.1 \mathrm{wt} . \%$, and avg. $\mathrm{TiO}_{2}=0.3 \mathrm{wt} . \%$. As in the case of the Al-hydroxides, the measured chemistry in the Fe-mineral phases does not correspond to the IMA accepted compositions. 

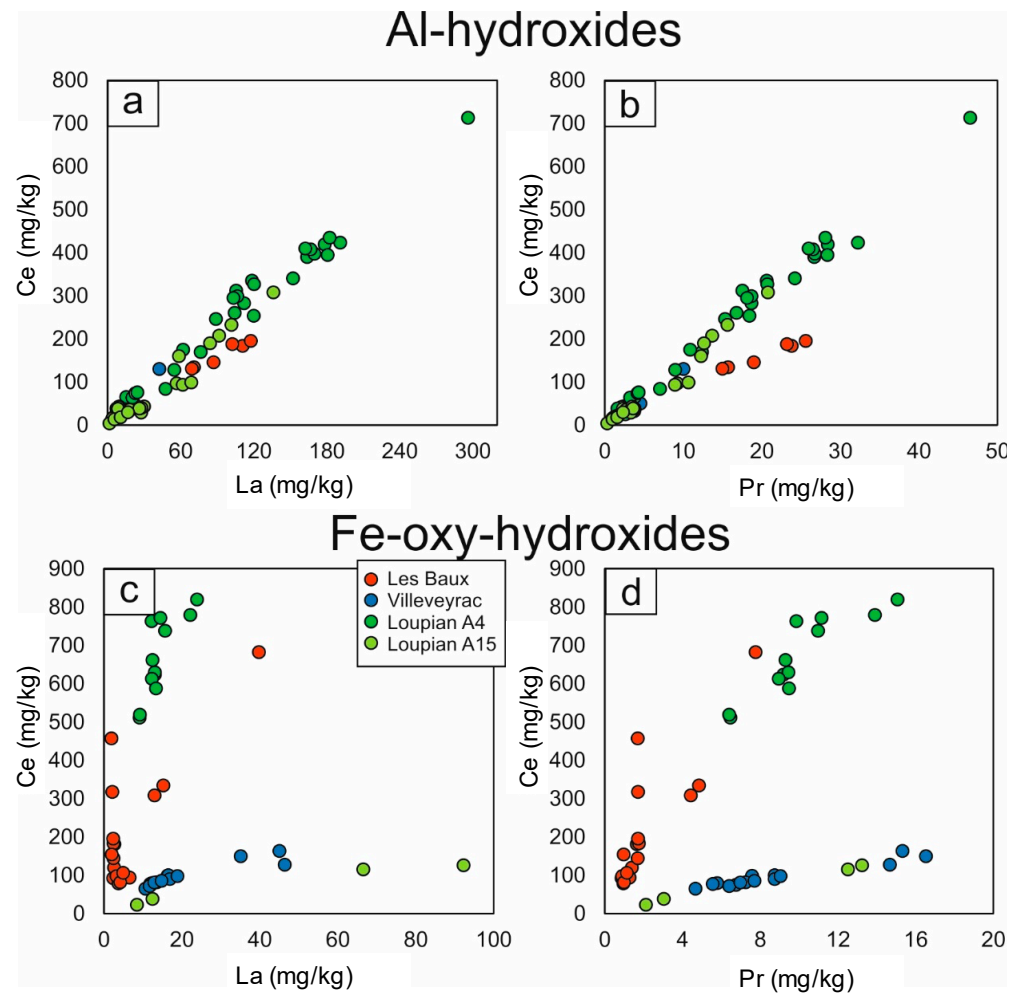

Figure 8. (a) La vs. Ce and (b) Ce vs. Pr ( $\mathrm{mg} / \mathrm{kg}$ ) binary diagrams of in-situ LA-ICP-MS analyses, on Al-hydroxides; (c) La vs. Ce and (d) Ce vs. Pr (mg/kg) binary diagrams of in-situ LA-ICP-MS analyses, on Fe-oxy-hydroxides.

On the basis of the mineralogy of the investigated Fe-minerals, it is possible to recognize several distinct characteristics of the samples. The hematite of Loupian A15 has the highest concentrations of bauxitophile elements among the samples analyzed: avg. $220 \mathrm{mg} / \mathrm{kg} \mathrm{Sc}$, avg. $1750 \mathrm{mg} / \mathrm{kg} \mathrm{V}$, avg. $4400 \mathrm{mg} / \mathrm{kg} \mathrm{Cr}$, avg. $60 \mathrm{mg} / \mathrm{kg} \mathrm{Co}$, and avg. $180 \mathrm{mg} / \mathrm{kg}$ Ni. The hematite of the Les Baux is on the other extreme, with the lowest concentrations of the same elements. Interestingly, the goethite of Loupian A4 is characterized by compositions in these elements dissimilar from all the hematites analyzed. In particular, this goethite has very low amounts of V (avg. $800 \mathrm{mg} / \mathrm{kg}$ ) and $\mathrm{Cr}$ (avg. $200 \mathrm{mg} / \mathrm{kg}$ ), and quite high Ni (avg. $230 \mathrm{mg} / \mathrm{kg}$ ) and Co (avg. $110 \mathrm{mg} / \mathrm{kg}$ ) (Figure 5). Gallium has similar concentrations in all the measured Fe-oxy-hydroxides (avg. $35 \mathrm{mg} / \mathrm{kg}$ ) (Figure 5).

Fe-oxy-hydroxides also contain REEs. In particular, the total REE amounts correspond to $254 \pm$ $188 \mathrm{mg} / \mathrm{kg}$ at Les Baux, $230 \pm 66 \mathrm{mg} / \mathrm{kg}$ at Villeveyrac, $827 \pm 131 \mathrm{mg} / \mathrm{kg}$ in Loupian A4, and $279 \pm$ $188 \mathrm{mg} / \mathrm{kg}$ in Loupian A15 (Figure 5). However, differently to the Al-hydroxides, these concentrations are dominated by Ce. In addition, looking at La vs. Ce and Ce vs. Pr binary diagrams (Figure 8), it is possible to see that the concentrations of these elements in the analyzed Fe-oxy-hydroxides follow decoupled positive linear arrays. In particular, the Loupian samples collected at the base (A15) and at the top (A4) of the bauxite profile show the lowest and the highest Ce concentrations, respectively. Observing the REE distribution in the chondrite-normalized spider diagrams (Figure 6), it is possible to see that Loupian A4 goethite has positive Ce anomalies, whereas Loupian A15 hematite has slight negative or no Ce anomalies, coherently with the bulk rock analyses, characterized by similar Ce anomalies in the chondrite-normalized patterns.

The REE distribution in Fe-oxy-hydroxides commonly mismatches the respective whole-rock bauxite composition in all the analyzed samples (more evidently in sample LBP 7, less in the Vil IV-5, Figure 6). This is better highlighted in bauxite-normalized patterns (Figure 7), where the Fe-oxy-hydroxides show flat MREE and HREE patterns with variable enrichment values over the 
LREEs relatively to the respective bauxite, and strong positive Ce anomalies in samples LBP 7 and LUP-A4.

\section{Discussion}

In the present study, LA-ICP-MS analyses of Al- and Fe-(oxy)-hydroxides were carried out, revealing that these minerals host variable amounts of $\mathrm{Al}, \mathrm{Fe}, \mathrm{Si}, \mathrm{Ti}$, as well as trace elements $(\mathrm{Ga}, \mathrm{Ni}, \mathrm{V}$, $\mathrm{Cr}, \mathrm{REEs})$. Even though the presence of minor amounts of $\mathrm{Fe}, \mathrm{Si}$, and $\mathrm{Ti}$ in $\mathrm{Al}$-hydroxides and $\mathrm{Al}$, $\mathrm{Si}$, and Ti in Fe-oxy-hydroxides might be an indication of mineral intergrowths, the same elements can also occur with the same concentrations as adsorbed cations onto the hydroxide surfaces [37-40]. If any of the selected LA-ICP-MS spots did correspond to a mineral intergrowth (for example Fe-oxy-hydroxides, anatase or kaolinite finely intergrown with boehmite), this should have produced only a minor impact on the corresponding trace element concentrations, simply because the amount of the major hydroxide is greatly dominant over any potential mixed mineral. At the same time, it is unlikely that the trace element concentration in the $\mathrm{Al}$ - and Fe-(oxy)-hydroxides was related to the occurrence of trace element mineral phases (e.g., REE minerals), because their presence would likely have produced peaks or jumps in the LA-ICP-MS time-resolved raw cps signal, that were not observed.

The presented data show that both Al- and Fe-(oxy)-hydroxides play a significant role in defining the REEs distribution in bauxite, together with the other REEs-bearing phases (e.g., monazite and xenotime) normally observed in this deposit-type [1-3]. In the studied samples, Al-hydroxides display on average an enrichment in LREEs, which resembles the REE distribution observed in the bulk rock. On the contrary, Fe-oxy-hydroxides are enriched in MREEs and HREEs and depleted in LREEs, with the exception of Ce that always shows large positive anomalies. The REE deportment in bauxite deposits has commonly been considered as being mostly influenced by the neo-formation of REE-phases such as Ce-oxides and REE-fluorocarbonates [22,26,41]. In previous works [14,15,22,41,42], it was shown that the formation of REEs-bearing minerals produces a fractionation between Ce and the other LREEs and HREEs. This process leads to a variable REE distribution within the bauxite profiles, with the highest grades observed alternatively, either at the top or at the bottom of the profiles, mainly in response to two distinct speciation modes:

(1) Ce enrichment at the top of the bauxite profiles: this characteristic is mainly related to Ce oxidation from a trivalent to the tetravalent state, associated with the precipitation of cerianite $\left[\left(\mathrm{Ce}^{4+}, \mathrm{Th}\right) \mathrm{O}_{2}\right][42]$. Cerium oxidation and consequent $\mathrm{CeO}_{2}$ precipitation may occur in the $\mathrm{pH}$ range of 5-6 [42].

(2) LREEs enrichment at the bottom of the profiles: it is explained by the per descensum model. This can be described as (i) REEs leaching at the top of the profile due to acidic soil solutions (a decrease of the $\mathrm{pH}$ of the surficial solutions, possibly due to a decrease of the ionic strength, can cause the conversion of $\mathrm{Ce}^{4+}$ to $\mathrm{Ce}^{3+}$ in the uppermost part of the karst deposit), (ii) downward percolation of the REEs-bearing fluids ( $\mathrm{REE}^{3+}$ transported in solution as fluoride complexes), (iii) acid buffering by the footwall limestones, and (vi) LREEs and $\mathrm{Ce}^{3+}$ fixations in neo-formed fluorocarbonates [26,41,42].

In a limited number of studies, it was suggested that, in association with the above-mentioned processes, the formation of Fe-oxy-hydroxides could also impact the REEs deportment $[9,42,43]$. For example, Mongelli [42] suggested that in the Apulian bauxites, REEs were scavenged by Fe-oxides from the Ce-depleted percolating solutions deriving from cerianite precipitation. This process was proposed for explaining anomalous concentrations of REEs in hematitic oolites, devoid of proper REE-minerals. The REE distribution in hematitic oolites was characterized by negative Ce anomalies. Gamaletsos et al. [9] suggested that the occurrence of REE anomalies in Fe-rich bauxites, relatively to Fe-poor bauxites in Greek deposits could have been related either to the presence of Ce-oxides or to epigenetic Ce sorption in Fe-oxides. The distribution of REEs in Fe-oxy-hydroxides in bauxites of southern France confirms the suggestions proposed in the mentioned literature: all the LA-ICP-MS analyses detected REE concentrations above the detection limits, indicating that REEs can be effectively 
associated with Fe-oxy-hydroxides, likely as adsorbed cations [44]. However, in contrast to Mongelli [42], the analyzed Fe-oxy-hydroxide crusts and oolites were always characterized by positive Ce anomalies. They were also enriched in MREEs and HREEs relative to the bulk bauxite, which, from the SEM-BSE observation, in turn, resulted to be free of cerianite. Experimental studies [44] have effectively shown that, under acidic conditions $(\mathrm{pH}<6)$, the Fe-oxy-hydroxides can adsorb high amounts of Ce, MREEs, and HREEs, in comparison with the other LREEs (i.e., La and Pr). Basic pHs enhance the adsorption of the other LREEs, thus masking the Ce anomaly [44]. For the above reasons, the REEs deportment observed in this study, and particularly in the sample collected from the top of the Loupian profile (LUP_A4), indicates that REE incorporation in Fe-oxy-hydroxides occurred under oxidizing conditions and $\mathrm{pH}<6$. Considering that in previous models the Ce concentration at the top of the bauxite profiles through cerianite precipitation is considered to occur in a $\mathrm{pH}$ range between 5 and 6 (e.g., [42]), our data strongly suggest that, under the same environmental conditions, the oxidation of $\mathrm{Ce}^{3+}$ to $\mathrm{Ce}^{4+}$ can be associated not only with cerianite formation, but also with $\mathrm{Ce}^{4+}$ incorporation/adsorption into/onto Fe-oxy-hydroxides. The HREEs enrichment and the less evident positive Ce anomaly in the LUP-A15 Fe-oxy-hydroxides could be related to the presence of Ce-depleted percolating solutions at the bottom of the bauxite horizon.

In all the studied samples, the Al-hydroxides display a general enrichment of LREEs in comparison to chondrite [33], but also relative to the corresponding Fe-oxy-hydroxides (see the samples LBP 7, LUP_A4, and LUP_A15). To the best of our knowledge, the incorporation of REE in Al-hydroxides has been never mentioned in the literature on bauxite deposits. However, there are several studies [45-48] dealing with experimental investigations on the adsorption of metals on Al-hydroxides, at ambient temperatures, atmospheric pressure, and variable $\mathrm{pH}$. Fraihurst and Warwick [45] investigated the sorption of $\mathrm{Eu}$, as analogs to other trivalent cations, onto goethite and boehmite, in the presence or absence of humic acid. It was shown that, in the absence of humic acids, Eu adsorption on both the minerals shows a non-linear increase with $\mathrm{pH}$, with a sharp adsorption increase at $\mathrm{pH}$ 4-6 for boehmite, and at pH 3-5.5 for goethite. The presence of variable concentrations of humic acid modifies this adsorption scheme, leading to a general increase of $\mathrm{Eu}$ adsorption at low $\mathrm{pH}(<5$ to 6$)$, and to a general decrease of adsorption at intermediate and high $\mathrm{pH}$. This behavior was recently confirmed by Kraemer et al. [47]. Granados-Correa et al. [40], while investigating Cd(II) adsorption onto boehmite and goethite, confirmed that adsorption is $\mathrm{pH}$-dependent, and in particular that the amount of metal adsorbed increases at $\mathrm{pH}$ values between 3.5 and 5. They also found that boehmite is characterized by an adsorption efficiency higher than goethite. This was considered to be related to the surface area of boehmite, which is larger than that of goethite, and contains a larger number of functional groups [40]. Therefore, the available literature supports the possibility that trivalent cations, like the REEs, can be adsorbed onto Al-hydroxides, similarly to the better-understood Fe-oxy-hydroxides. Looking at the REE concentrations in the French bauxites, in general, and in particular, considering the sample LBP 7, it seems that Al-hydroxides have preferentially incorporated LREEs (except Ce), with respect to the HREEs, in contrast to Fe-oxy-hydroxides. This is not surprising given that in the $\mathrm{pH}$ range where cation adsorption onto boehmite is favored ( $\mathrm{pH} 4$ to 6 [45]), the Fe-oxy-hydroxides preferentially incorporate $\mathrm{Ce}$, and HREEs [44]. Other features can be observed in the Loupian profile, where Al-hydroxides in the bauxite-normalized diagrams show almost mirrored REEs patterns in comparison with Fe-oxy-hydroxides. Specifically, at the top of the Loupian profile, where Fe-oxy-hydroxides are characterized by positive Ce anomalies and high HREE concentrations, the Al-hydroxides have Ce-depleted and LREE-enriched patterns. At the bottom of the profile, Al-hydroxides are still on average enriched in LREEs, but also have small positive Ce anomalies, whereas Fe-oxy-hydroxides show strong HREE enrichments with no Ce anomalies. This distribution might confirm: (i) the presence of Ce-depleted solutions percolating from the top toward the bottom of the bauxite horizon [42], and (ii) REE partitioning between Al-hydroxides and Fe-oxy-hydroxides [44], with the former preferentially hosting the LREEs. 
Slightly different is the case of sample Vil IV-5, where both Fe-oxy-hydroxides and Al-hydroxides have similar chondrite-normalized patterns (Figure 6 b), and only differ because the former are richer in MREEs and HREEs than the latter (Figure 7c,d). Therefore, in contrast with the other samples, in Vil IV-5, Al-hydroxides apparently do not show LREE enrichments. This peculiar feature could derive from a combination of distinct processes: (i) the formation of authigenic LREE-minerals in not-investigated sections of the deposit, that has produced LREE-depleted solutions from the start, later reflected in the anomalous patterns of the Al-hydroxides [42], or (ii) in-situ acidic leaching of bauxite (also supported by the occurrence of kaolinite) that has progressively depleted of LREEs the more reactive Al-hydroxides in respect to the Fe-oxy-hydroxides [40]. However, a more careful and large-scale investigation is required to determine which processes affected the Villeveyrac deposit.

From an applied point of view, the most relevant outcome of the present study is the detection of REEs adsorbed onto Al-hydroxides. As mentioned in the introduction, there is an ongoing debate on whether to consider bauxite deposits and/or red muds as potential REE resources [4,22-28]. In a recent paper on Greek red muds [27], it was shown that during the Bayer process, while Ga is principally accumulated in process liquors, REEs have the tendency to remain unaffected in solid phases, fully ending up in the bauxite residue, mostly in the form of a new LREE ferrotitanate phase $\left[(\mathrm{REE}, \mathrm{Ca}, \mathrm{Na})(\mathrm{Ti}, \mathrm{Fe}) \mathrm{O}_{3}\right]$, considered to derive from digestion of preexisting REE-minerals, originally occurring in the bauxite feed [27]. However, it was also shown that possible preexisting REE-bearing minerals (e.g., monazite, REE-fluorocarbonates) also occur as untouched mineral phases in the bauxite residue [27]. Even though we have not analyzed any French red mud, by analogy with the data presented in the present paper, in our opinion this suggests that the mentioned LREE ferrotitanate was not produced by digestion/reaction of former monazite or REE-fluorocarbonates, but by REEs, Fe and Ti originally contained into Al-hydroxides and released into the liquor after their digestion. If confirmed, this would also suggest that REEs adsorbed onto Al-hydroxides, once released, rapidly form compounds with other free elements occurring in the liquor. Therefore, an interesting issue to develop in the future is whether (and how) REEs released during Al-hydroxide digestion can be efficiently recovered from the pregnant leach liquor, as routinely done for Ga.

\section{Conclusions}

(1) LA-ICP-MS analyses of Al-hydroxides and Fe-oxy-hydroxides carried out on four samples of French bauxites revealed that these minerals host variable amounts of $\mathrm{Al}, \mathrm{Fe}, \mathrm{Si}$, $\mathrm{Ti}$, and trace elements (Ga, Ni, V, Cr, REEs).

(2) Al-hydroxides display an enrichment in LREEs, which resembles the REE distribution observed in the bulk rock. Fe-oxy-hydroxides are instead enriched in MREEs and HREEs and depleted in LREEs, with the exception of Ce that always shows large positive anomalies. REEs are likely associated with the Al- and Fe-(oxy)-hydroxides as adsorbed cations.

(3) The presented data strongly suggest that positive $\mathrm{Ce}$ anomalies observed in chondrite-normalized patterns of bulk bauxite samples are not only associated with cerianite formation, but also with the oxidation of $\mathrm{Ce}^{3+}$ to $\mathrm{Ce}^{4+}$ and following $\mathrm{Ce}^{4+}$ incorporation/adsorption into/onto Fe-oxy-hydroxides.

(4) Even though the present study was conducted on a limited number of samples, the occurrence of REEs in Al-hydroxides is of notable interest, because it is likely that REEs are released into the pregnant liquor together with $\mathrm{Al}$ during the digestion step of the Bayer process. Therefore, by using a specific collector, there is potential for REE efficient recovery, as it is routinely done for Ga.

Supplementary Materials: The following are available online at http://www.mdpi.com/2075-163X/9/9/504/s1.

Author Contributions: Conceptualization, N.M., F.P. and L.S.; software, N.M., F.P., M.T.; validation, N.M., F.P., M.T.; methodology and formal analysis, G.B., A.M., and L.S.; investigation, N.M., F.P., C.C.-M., S.C., G.S., and M.T.; data curation, N.M., F.P.; writing-original draft preparation, N.M., F.P.; writing-review \& editing, C.C.-M., M.B.; project administration, N.M.; funding acquisition, N.M., L.S. 
Funding: The research leading to these results has received funding from the "Programma per il finanziamento della ricerca di Ateneo 2016-Progetto CEB", granted by Università degli Studi di Napoli Federico II (Italy) to Nicola Mondillo. Other funding derived from the European Union's Horizon 2020 research and innovation program, by a Marie Skłodowska-Curie Individual Fellowship (Project name GOSSAN, number 751103) awarded to R. Herrington, supporting the fellowship of L. Santoro.

Acknowledgments: The authors are indebted to R. de'Gennaro and J. Buret for the help, respectively during SEM and LA-ICP-MS analyses. Our acknowledgments are also for the three anonymous reviewers, whose comments have greatly enhanced the quality of the paper. G. Mongelli is thanked for the editorial work.

Conflicts of Interest: The authors declare no conflict of interest.

\section{References}

1. Bárdossy, G.; Aleva, G.J.J. Lateritic Bauxites; Elsevier: Amsterdam, The Netherlands, 1990; 624p.

2. Bárdossy, G. Karst Bauxites, Bauxite Deposits on Carbonate Rocks (Developments in Economic Geology); Elsevier: Amsterdam, The Netherlands, 1982; p. 441.

3. Boni, M.; Rollinson, G.; Mondillo, N.; Balassone, G.; Santoro, L. Quantitative mineralogical characterization of karst bauxite deposits in the southern Apennines, Italy. Econ. Geol. 2013, 108, 813-833. [CrossRef]

4. Lee Bray, E. Bauxite and alumina. In Mineral Commodity Summaries; U.S. Geological Survey: Reston, VA, USA, 2019.

5. Hind, A.R.; Bhargava, S.K.; Grocott, S.C. The surface chemistry of Bayer process solids: A review. Colloids Surf. A Physicochem. Eng. Asp. 1999, 146, 359-374. [CrossRef]

6. Mongelli, G.; Boni, M.; Oggiano, G.; Mameli, P.; Sinisi, R.; Buccione, R.; Mondillo, N. Critical metals distribution in Tethyan karst bauxite: The Cretaceous Italian ores. Ore Geol. Rev. 2017, 86, 526-536. [CrossRef]

7. Abedini, A.; Calagari, A.A. REE geochemical characteristics of titanium-rich bauxites: The Permian Kanigorgeh horizon, NW Iran. Turk. J. Earth Sci. 2014, 23, 513-532. [CrossRef]

8. Gamaletsos, P.N.; Godelitsas, A.; Mertzimekis, T.J.; Göttlicher, J.; Steininger, R.; Xanthos, S.; Berndt, J.; Klemme, S.; Kuzmin, A.; Bárdossy, G. Thorium partitioning in Greek industrial bauxite investigated by synchrotron radiation and laser-ablation techniques. Nucl. Instrum. Methods Phys. Res. Sect. B Beam Interact. Mater. At. 2011, 269, 3067-3073. [CrossRef]

9. Gamaletsos, P.N.; Godelitsas, A.; Filippidis, A.; Pontikes, Y. The rare earth elements potential of Greek bauxite active mines in the light of a sustainable REE demand. J. Sustain. Metall. 2018, 5, 20-47. [CrossRef]

10. Hanilçi, N. Geological and geochemical evolution of the Bolkardaği bauxite deposits, Karaman, Turkey: Transformation from shale to bauxite. J. Geochem. Explor. 2013, 133, 118-137. [CrossRef]

11. Karadă̆, M.M.; Küpeli, Ş.; Arýk, F.; Ayhan, A.; Zedef, V.; Döyen, A. Rare earth element (REE) geochemistry and genetic implications of the Mortaş bauxite deposit (Seydişehir/Konya-Southern Turkey). Chem. Erde 2009, 69, 143-159. [CrossRef]

12. Ling, K.Y.; Zhu, X.-Q.; Tang, H.S.; Wang, Z.G.; Yan, H.W.; Han, T.; Chen, W.Y. Mineralogical characteristics of the karstic bauxite deposits in the Xiuwen ore belt, Central Guizhou Province, Southwest China. Ore Geol. Rev. 2015, 65, 84-96. [CrossRef]

13. Mameli, P.; Mongelli, G.; Oggiano, G.; Dinelli, E. Geological, geochemical and mineralogical features of some bauxite deposits from Nurra (western Sardinia, Italy): Insights on conditions of formation and parental affinity. Int. J. Earth Sci. 2007, 96, 887-902. [CrossRef]

14. Mondillo, N.; Boni, M.; Balassone, G.; Rollinson, G. Karst bauxites in the Campania Apennines (southern Italy): A new approach. Period. Mineral. 2011, 80, 407-432.

15. Putzolu, F.; Piccolo Papa, A.; Mondillo, N.; Boni, M.; Balassone, G.; Mormone, A. Geochemical Characterization of Bauxite Deposits from the Abruzzi Mining District (Italy). Minerals 2018, 8, 298. [CrossRef]

16. Torró, L.; Proenza, J.A.; Aiglsperger, T.; Bover-Arnal, T.; Villanova-de-Benavent, C.; Rodríguez-García, D.; Ramírez, A.; Rodríguez, J.; Mosquea, L.A.; Salas, R. Geological, geochemical and mineralogical characteristics of REE-bearing Las Mercedes bauxite deposit, Dominican Republic. Ore Geol. Rev. 2017, 89, 114-131. [CrossRef] 
17. Wang, Q.; Deng, J.; Liu, X.; Zhang, Q.; Sun, S.; Jiang, C.; Zhou, F. Discovery of the REE minerals and its geological significance in the Quyang bauxite deposit, West Guangxi, China. J. Asian Earth Sci. 2010, 39, 701-712. [CrossRef]

18. Yu, W.; Wang, R.; Zhang, Q.; Du, Y.; Chen, Y.; Liang, Y. Mineralogical and geochemical evolution of the Fusui bauxite deposit in Guangxi, South China: From the original Permian orebody to a Quarternary Salento-type deposit. J. Geochem. Expl. 2014, 146, 75-88. [CrossRef]

19. Zarasvandi, A.; Charchi, A.; Carranza, E.J.M.; Alizadeh, B. Karst bauxite deposits in the Zagros Mountain belt, Iran. Ore Geol. Rev. 2008, 34, 521-532. [CrossRef]

20. Jaskula, B.W. Gallium. In Mineral Commodity Summaries; U.S. Geological Survey: Reston, VA, USA, 2019.

21. Authier-Martin, M.; Forte, G.; Ostap, S.; See, J. The mineralogy of bauxite for producing smelter-grade alumina. JOM 2001, 53, 36-40. [CrossRef]

22. Mongelli, G.; Boni, M.; Buccione, R.; Sinisi, R. Geochemistry of the Apulian karst bauxites (southern Italy): Chemical fractionation and parental affinities. Ore Geol. Rev. 2014, 63, 9-21. [CrossRef]

23. Mongelli, G.; Buccione, R.; Gueguen, E.; Langone, A.; Sinisi, R. Geochemistry of the Apulian allochthonous karst bauxite, Southern Italy: Distribution of critical elements and constraints on Late Cretaceous Peri-Tethyan palaeogeography. Ore Geol. Rev. 2016, 77, 246-259. [CrossRef]

24. Goodenough, K.M.; Schilling, J.; Jonsson, E.; Kalvig, P.; Charles, N.; Tuduri, J.; Deady, É.A.; Sadeghi, M.; Schiellerup, H.; Müller, A. Europe's rare earth element resource potential: An overview of REE metallogenetic provinces and their geodynamic setting. Ore Geol. Rev. 2016, 72, 838-856. [CrossRef]

25. Mouchos, E.; Wall, F.; Williamson, B.J.; Palumbo-Roe, B. Easily leachable rare earth element phases in the Parnassus-Giona bauxite deposits, Greece. Bull. Geol. Soc. Greece 2016, 50, 1952-1958. [CrossRef]

26. Deady, É.A.; Mouchos, E.; Goodenough, K.M.; Williamson, B.J.; Wall, F. A review of the potential for rare-earth element resources from European red muds: Examples from Seydişehir, Turkey and Parnassus-Giona, Greece. Mineral. Mag. 2016, 80, 43-61. [CrossRef]

27. Vind, J.; Malfliet, A.; Blanpain, B.; Tsakiridis, P.E.; Tkaczyk, A.H.; Vassiliadou, V.; Panias, D. Rare Earth Element Phases in Bauxite Residue. Minerals 2018, 8, 77. [CrossRef]

28. Vind, J.; Alexandri, A.; Vassiliadou, V.; Panias, D. Distribution of Selected Trace Elements in the Bayer Process. Metals 2018, 8, 327. [CrossRef]

29. Herrington, R.; Mondillo, N.; Boni, M.; Thorne, R.; Tavlan, M. Bauxite and Nickel-Cobalt Lateritic Deposits of the Tethyan Belt. In Tectonics and Metallogeny of the Tethyan Orogenic Belt, Special Publication; Richards, J., Ed.; SEG Inc.: Littleton, CO, USA, 2016; Volume 19, pp. 349-387.

30. Nicolas, J. Nouvelles données sur la genése des bauxites à mur karstique du sud-est de la France. Mineral. Depos. 1968, 3, 18-33. [CrossRef]

31. Guendon, J.L.; Parron, C. Les phénomènes karstiques dans les processus de bauxitisation sur substrat carbonaté. Ann. Soc. Géol. Belg. 1985, 108, 85-92.

32. Combes, P.J. Typologie, cadre géodynamique et génèse des bauxites françaises. Geodin. Acta 1990, 4, 91-109. [CrossRef]

33. McDonough, W.F.; Sun, S.S. The composition of the Earth. Chem. Geol. 1995, 120, 223-253. [CrossRef]

34. Zachariáš, J.; Wilkinson, J. Exlam 2000: Excel VBA application for processing of transient signals from laser ablation (LA-ICPMS) of fluid inclusions and solid phases. In Proceedings of the ECROFI-XIX Biennial Conference on European Current Research on Fluid Inclusions, Bern, Switzerland, 17-20 July 2007.

35. Longerich, H.P.; Jackson, S.E.; Günther, D. Laser ablation inductively coupled plasma mass spectrometric transient signal data acquisition and analyte concentration calculation. J. Anal. At. Spectrom. 1996, 11, 899-904. [CrossRef]

36. Dare, S.; Barnes, S.J.; Beaudoin, G.; Méric, J.; Boutroy, E.; Potvin-Doucet, C. Trace elements in magnetite as petrogenetic indicators. Mineral. Depos. 2014, 49, 785-796. [CrossRef]

37. Hiemstra, T.; Barnett, M.O.; van Riemsdijk, W.H. Interaction of silicic acid with goethite. J. Colloid Interface Sci. 2007, 310, 8-17. [CrossRef] [PubMed]

38. Hiemstra, T.; van Riemsdijk, W.H. Adsorption and surface oxidation of Fe(II) on metal (hydr)oxides. Geochim. Cosmochim. Acta 2007, 71, 5913-5933. [CrossRef]

39. Parkinson, G.S. Iron oxide surfaces. Surf. Sci. Rep. 2016, 71, 272-365. [CrossRef] 
40. Granados-Correa, F.; Corral-Capulin, N.G.; Olguín, M.T.; Acosta-León, C.E. Comparison of the Cd(II) adsorption processes between boehmite $(\gamma-\mathrm{AlOOH})$ and goethite $(\alpha-\mathrm{FeOOH})$. Chem. Eng. J. 2011, 171, 1027-1034. [CrossRef]

41. Maksimović, Z.; Pantó, G.Y. Contribution to the geochemistry of the rare earth elements in the karst-bauxite deposits of Yugoslavia and Greece. Geoderma 1991, 51, 93-109. [CrossRef]

42. Mongelli, G. Ce-anomalies in the textural components of Upper Cretaceous karst bauxites from the Apulian Carbonate Platform (southern Italy). Chem. Geol. 1997, 140, 69-79. [CrossRef]

43. Bolanz, R.M.; Kiefer, S.; Göttlicher, J.; Steininger, R. Hematite $\left(\alpha-\mathrm{Fe}_{2} \mathrm{O}_{3}\right)$-A potential $\mathrm{Ce}^{4+}$ carrier in red mud. Sc. Total. Environ. 2018, 622-623, 849-860. [CrossRef] [PubMed]

44. Liu, H.; Pourret, O.; Guo, H.; Bonhoure, J. Rare earth elements sorption to iron oxyhydroxide: Model development and application to groundwater. Appl. Geochem. 2017, 87, 158-166. [CrossRef]

45. Fairhurst, A.J.; Warwick, P. The influence of humic acid on europium-mineral interactions. Colloids Surf. A Physicochem. Eng. Asp. 1998, 145, 229-234. [CrossRef]

46. Granados-Correa, F.; Jiménez-Becerril, J. Chromium (VI) adsorption on boehmite. J. Hazard. Mater. 2009, 162, 1178-1184. [CrossRef]

47. Kraemer, S.M.; Xu, J.; Raymond, K.N.; Sposito, G. Adsorption of $\mathrm{Pb}(\mathrm{II})$ and $\mathrm{Eu}(\mathrm{III})$ by Oxide Minerals in the Presence of Natural and Synthetic Hydroxamate Siderophores. Environ. Sci. Technol. 2002, 36, 1287-1291. [CrossRef] [PubMed]

48. McBride, M.B. $\mathrm{Cu}^{2+}$-adsorption characteristics of aluminum hydroxide and oxyhydroxides. Clays Clay Miner. 1982, 30, 21-28. [CrossRef]

(C) 2019 by the authors. Licensee MDPI, Basel, Switzerland. This article is an open access article distributed under the terms and conditions of the Creative Commons Attribution (CC BY) license (http://creativecommons.org/licenses/by/4.0/). 